75 years of Agricultural University - Plovdiv

JUBILEE SCIENTIFIC INTERNATIONAL

CONFERENCE Plovdiv 26-28 November 2020
PERSPECTIVES ON AGRICULTURAL SCIENCE AND INNOVATIONS FOR SUSTAINABLE FOOD SYSTEMS

DOI: 10.22620/agrisci.2021.29.012

\title{
USE OF GROWTH REGULATORS AND SAPROPHYTIC FUNGI TRICHODERMA VIRIDE PERS EX FR. TO IMPROVE THE HEALTH STATUS OF THE SOIL IN PEPPER FIELD
}

\author{
Olga Georgieva*, Natalia Karadzhova
}

Maritsa Vegetable Crops Research Institute (MVCRI), 32 Brezovsko shosse, 4003 - Plovdiv, Bulgaria

\section{*E-mail: olgaizk@abv.bg}

\begin{abstract}
The article presents studies on the influence of the microbiological product "Trichodermine", bio-organic fertilizers and growth regulators based on humic acids „Nagro”, „Stimix”, „BioLife” and mineral fertilizers (NPK) on the biological activity of the soil, the degree of disease, caused by Alternaria capsici-annui Savul \& Sandu and pepper yield in field production. It has been found that the differences in the "Soil Biological Activity" indicator depends on the number of micro-organisms, the composition (species diversity) and the percentage of major Micromycetes. Organic products help optimize soil health and reduce the total content of fungal colonies, and in the Micromycetes composition the fungus Trichoderma $s p$. is more common. When mineral fertilizers are introduced, the number of fungal pathogens and toxin producers increases. A higher total yield was obtained in variants with biological treatment. The increase in yield is between $9 \%$ and $29 \%$.
\end{abstract}

Keywords: vegetable production, biological activity of the soil, resistance to diseases.

\section{INTRODUCTION}

The development of fungal diseases in the vegetable field crops is one of the limiting factors of yield. Black leaf spots (Alternaria capsici-annui Savul \& Sandu) is one of the most important economic diseases on pepper. According to some authors (Chulkina, 1995; Bakker et al., 2014), the intensity of the disease depends on the amount of soil and seed infection and the ecological and technological conditions of cultivation. The concept of biological protection of plants is determined by the amount of plant organic matter in the soil, the introduction of organic fertilizers and the use of biological agents (Rudakov, 2006). Growth regulators and organic fertilizers based on natural materials have received considerable attention from both the scientific community and commercial enterprises, especially in the last two and a half decades (Apone et al., 2010; Craigie, 2011; Brown \& Saa, 2015; Du Jardin,
2015; Yakhin et al., 2017). Biostimulants offer a potentially novel approach to regulating physiological processes in plants to stimulate growth, relieve stress and increase yields (Belakbir et al., 1998; Bhattacharyya \& Jha, 2012; Ikrina \& Kolbin, 2004; Linser et al., 2006; Mora et al., 2010). The influence of organic fertilizers on the intensity of diseases in vegetable crops has been studied by a number of researchers (Colla et al., 2015; Di Marco \& Osti, 2009; Dixon \&Walsh, 2004; FuentesRamirez \& Caballero-Mellado, 2006; Hernandez et al., 2014; Hernandez-Herrera et al., 2015). It was found that the use of organic fertilizers on greenhouse tomatoes changes the balance of nutrition and affects the phytosanitary condition of this crop (Georgieva, 2013). The aim of this work is to study the effect of new growth regulators on the following indicators in the production of pepper: the total microbiological activity and structural composition of soil micromycetes, 
75 years of Agricultural University - Plovdiv JUBILEE SCIENTIFIC INTERNATIONAL CONFERENCE Plovdiv 26-28 November 2020
PERSPECTIVES ON AGRICULTURAL SCIENCE AND INNOVATIONS FOR SUSTAINABLE FOOD SYSTEMS
Alternaria damage index of black spots, the total yield and percentage of standard products.

\section{MATERIALS AND METHODS}

The experimental work was carried out in 2009-2011 on the territory of Maritsa Vegetable Crops Research Institute on alluvialmeadow soil with the pepper variety "Kurtovska kapia". Soil characteristics: humus content-2.1\% (Turin), mineral nitrogen $\left(\mathrm{NH}_{4}+\right.$ $\mathrm{NO}_{3}-\mathrm{N}$ ), determined by the distillation method$1.8 \mathrm{mg} / 100 \mathrm{~g}$ soil, mobile $\mathrm{P}_{2} \mathrm{O}_{5}-16.1 \mathrm{mg} / 100 \mathrm{~g}$ and mobile $\mathrm{K}_{2} \mathrm{O}-18.2 \mathrm{mg} / 100 \mathrm{~g}$ soil (EgnerRhyme), soil reaction $\mathrm{Ph} / \mathrm{H}_{2} \mathrm{O} /-\quad 6.9$ (potentiometric). The experiment was carried out by the block method in four replicates (100 replicated plants), with a test area of $12.8 \mathrm{~m}^{2}$. The strategic direction of the experiment included the study of the influence of the Trichoderma viride Pers, the bio-fertilizers „Nagro”, „Stimix”, „BioLife” on the total biogenic of soil, composition and structure of the soil Micromycetes and the development of black spots (Alternaria capsici-annui Savul \& Sandu). For this purpose, the pepper seeds were treated with the bio-fertilizers "Nagro" and "Stimix" in concentration $1: 100$ for $4 \mathrm{~h}$ followed by treatment of plants with the same bio-fertilizers in concentration 1:100 in the blooming phase and after the first harvest. The bioproduct "BioLife" was introduced into the rhizosphere of the plants as a liquid solution in concentration $500 \mathrm{ml} / 200 \mathrm{~L} \mathrm{H}_{2} \mathrm{O}$ at $5 \mathrm{~L} / \mathrm{m}^{2}$ immediately after planting, in the flowering period. The bio-product "Trichodermine" (Trichoderma viride Pers ex Fr.) was introduced in the soil at $40 \mathrm{~kg} / \mathrm{Ha}$. Experimental variants were carried out on a standard and double reduced mineral background. The standard mineral background contained $\mathrm{N}_{16} \mathrm{P}_{20} \mathrm{~K}_{22}$ : ammonium nitrate 500 $\mathrm{kg} / \mathrm{Ha}$, super phosphate - $450 \mathrm{~kg} / \mathrm{Ha}$, and potassium sulfate $-450 \mathrm{~kg} / \mathrm{Ha}$. Phosphorus and potassium fertilizers were introduced during the autumn soil treatment, nitrogen - during the vegetation. Reduced mineral background contained $\mathrm{N}_{8} \mathrm{P}_{10} \mathrm{~K}_{11}$ respectively.

Indicators: Total\% Yield ( $\mathrm{kg} \mathrm{/} \mathrm{Ha),}$ Alternaria black spot Attack Index on the leaves, Percentage of Diseased fruits (\%), Total Soil Biological Activity (CFU count per $1 \mathrm{~g}$ dry soil, amount of fungal colonies in $1 \mathrm{~g}$ of dry soil). The attack rate of Alternaria capsiciannui was counted on a five-digit scale (Gannibal et al., 2011): 0 - no symptoms, 1single spots, 2- to $25 \%, 3-26-50 \%$, 4- over 50 $\%$ of the leaf surface is covered with spots, the plant is strongly suppressed. The attack index was calculated using Mc. Kinnly formula, the effect of using organic fertilizers - Abbott formula. The percentage of diseased fruits with signs of Alternaria capsici-annui was counted during mass harvesting (\%). The microbiological analysis of the soil samples was made at the beginning, middle and end of the vegetation - after harvesting the produce. The biological activity of the soil was determined by the standard microbiological methods of cultivation of microorganisms on elective nutrient media (Zvyagintsev, 1991).

The statistical processing of the obtained experimental data was made with the program Excel (Microsoft Office 2002), Windows XP. The results of the study were analyzed by the standard statistical procedure and presented as means from three replicates.

fertilizers:

Characterization of organic liquid

"Nagro" - 19.17\% dry substance; 10.29 g/l organic substance; Ph-8.5; N(common)$0.77 \mathrm{~g} / \mathrm{L}$; phosphorus $\left(\mathrm{P}_{2} \mathrm{O}_{5}\right)-387 \mathrm{ml} / \mathrm{L}$; potassium $\left(\mathrm{K}_{2} \mathrm{O}\right)-4624 \mathrm{ml} / \mathrm{L} ; \mathrm{C}: \mathrm{N}(6: 1)$; micro elements $\mathrm{Cu}-0.51 \mathrm{ml} / \mathrm{L}, \mathrm{MgO}-541 \mathrm{ml} / \mathrm{L}$, Mo$669 \mathrm{ml} / \mathrm{l}, \mathrm{S}-1.8 \%$, Zn-6.0 mg/Kg, Fe- $154 \mathrm{ml} / \mathrm{L}$, B-1.02 ml/l, humic acids- $1.63 \mathrm{~g} / \mathrm{L}$, polyacids$8.67 \mathrm{~g} / \mathrm{L}$;

„Stimix” - free amino acids-15-30 g/l, humic acids- 30-50 g/L, organic silicon, live microbial crops, biologically active substances. 
75 years of Agricultural University - Plovdiv JUBILEE SCIENTIFIC INTERNATIONAL CONFERENCE Plovdiv 26-28 November 2020
PERSPECTIVES ON AGRICULTURAL SCIENCE AND INNOVATIONS FOR SUSTAINABLE FOOD SYSTEMS
„BioLife” - is a combined highly concentrated bacterial preparation. It contains enzymes and non-pathogenic microorganisms and an active ferment that accelerates and increases the development of microorganisms and stimulates the direct action of soil bacteria.

„Trichodermine” (Trichoderma viride Pers ex Fr., strain $\mathrm{N}^{\mathrm{o}} 12$ ) - a bio-product with a titre $2.10^{10} \mathrm{c} / \mathrm{g}$, obtained by the solid phase technology.

\section{RESULTS AND DISCUSSION}

The results of our research confirm that the sanitary condition of the soil depends on the total action of factors associated with crop cultivation. The microbiological analysis of the soil samples taken from the pepper field at the beginning, middle and end of vegetation shows that the biological activity of the soil in the experiment changes during the whole growing season (Table 2). The Total Biological Activity of the soil in the experience with pepper increases twice during the vegetation. The increase of the soil biological activity in control variant with mineral fertilizers $\left(\mathrm{N}_{16} \mathrm{P}_{20} \mathrm{~K}_{22}\right)$ during the flowering phase - the first harvest is 40 per cent, at the end of the vegetation -26 per cent. This shows that with a standard fertilization of the pepper with the mineral fertilizer complex (NPK) the mineralization process is the highest in the middle of the vegetation when the first harvesting takes place. At the end of the vegetation the soil biological activity is still high, but with lower values than those calculated in the middle of the vegetation. The distribution of the colonies of microorganisms shows the increase in the number of bacteria and Actinomycetes in the middle of vegetation with the subsequent equalization of this indicator towards the end of the period in almost all variants. The number of fungi colonies is the highest at the beginning of the vegetation and varies, depending on the use of fertilizers and the bio-products. The amount of imported fertilizers affects the biological activity of the soil. The introduction of the standard dose of mineral fertilizers $\left(\mathrm{N}_{16} \mathrm{P}_{20} \mathrm{~K}_{22}\right)$ into the control variant enhances the process of biological activity. The amount of fungi colonies in $1 \mathrm{~g}$ of soil in the middle of vegetation is the highest in the full mineral fertilization options - $\mathrm{N}_{16} \mathrm{P}_{20} \mathrm{~K}_{22}$. Probably, a major factor regulating the number of microorganisms in the soil is the nitrogen content. It is well known that the study of the influence of the structural composition of the Micromycetes complex in the soil is limited to four functional groups of fungi: saprophytes, parasites, antagonists and fungi producers of toxins. In the variant with mineral fertilizers dominate fungi producing toxins - -Penicillium sp., Aspergillus spp. and Fusarium spp. (Table 3). The use of the bioproducts "Trichodermine", "Nagro", "Stimix" and "BioLife" leads to the optimization of the sanitary state of the soil at the expense of the lower content of fungi colonies in the variants with bioproducts. The content of pathogenic fungi in soil samples with "Trichodermine" and "Bio Life" is significantly lower than in the control variants; except for Trihoderma spp. colonies are more common.

The effect of the bioproducts is better expressed on the reduced mineral background. Therefore, the introduction of "BioLife" into the rhizosphere during planting on the doublereduced background increases the Biological Activity of the Soil by 51per cent to the middle and by 43 per cent towards the end of the vegetation. A study of the composition of the microorganisms in the soil shows that the amount of bacteria in this variant doubles from $1.14 \mathrm{million} / \mathrm{g}$ in the beginning to 1.89 million/g - to the middle and up to 2.05 million/g of dry soil - at the end of the vegetation. Accordingly, in the same embodiment, the growth of Actinomycetes ranges from 0.14 million/g to 0.27 million/g in dry soil. The content of Micromycetes in the 
75 years of Agricultural University - Plovdiv JUBILEE SCIENTIFIC INTERNATIONAL CONFERENCE Plovdiv 26-28 November 2020
PERSPECTIVES ON AGRICULTURAL SCIENCE AND INNOVATIONS FOR SUSTAINABLE FOOD SYSTEMS soil is maximal at the beginning of the vegetation, after which there is a reduction of the fungi in the variant with the mineral nutrition as well as in the variant with bioproduct. The content of Micromycetes in the soil is maximal at the beginning of the growing season, after which there is a decrease in the fungi in the variants with mineral nutrition as well as in the variants with bioproducts. The introduction of bioproducts on the reduced mineral background of bio-products creates favorable conditions for the development of microorganisms from all major groups. This guarantees the stability of the functional links between the major ecological trophic groups of microorganisms. The positive influence of biofertilizers on the development of fungi diseases in vegetables has been proven by many researchers (Yegoshin, 2008; Yakovlev, 2006).

Monitoring of incidence during harvesting showed differences in the rate of damage from Alternaria capsici-annui depending on the rate of application of mineral (NPK) fertilizers and the applied bioproduct. In variants with mineral fertilizers, the development of black spots of Alternaria spp. is $30-32 \%$, with "Biolife" - 23-29\%. The standard rate of basic mineral fertilizers $\left(\mathrm{N}_{16} \mathrm{P}_{20} \mathrm{~K}_{22}\right)$ is the most effective for growing plants treated with the bioproducts "Nargo" and ,Stimix”. In variants with seed treatment in "Nagro" solution, the disease reduction is 45 per cent on background $\left(\mathrm{N}_{8} \mathrm{P}_{10} \mathrm{~K}_{11}\right)$ and 55 per cent on background $\left(\mathrm{N}_{16} \mathrm{P}_{20} \mathrm{~K}_{22}\right)$. The seed treatment with "Stimix" solution reduces the development of black spots in pepper at 6 per cent on background $\left(\mathrm{N}_{8} \mathrm{P}_{10} \mathrm{~K}_{11}\right)$ and 47 per cent on background $\left(\mathrm{N}_{16} \mathrm{P}_{20} \mathrm{~K}_{22}\right)$. Compared with the control variants, the effect of "BioLife" biofertilizer ranges from 11 per cent on reduced to 28 per cent on a standard mineral background. The single soil treatment with the bioproduct "Trihodermine" produced good results for both fertilizer norms - the standard $\left(\mathrm{N}_{16} \mathrm{P}_{20} \mathrm{~K}_{22}\right)$ and the double reduced $\left(\mathrm{N}_{8} \mathrm{P}_{10} \mathrm{~K}_{11}\right)$. The highest efficacy against Alternaria black spots in the crop (56 per cent) was registered from the application of the bioproduct ,Trihodermine”.

Our results confirm that the use of microbial products in the vegetable crops stimulates growth, yield and product quality. It was found that when growing pepper from treated seeds with growth regulators and applying Trichodermin to the soil, the dose of mineral fertilizers can be reduced by half without the risk of crop loss from Alternaria capsici-annui. As can be seen from table 3, the yield of the pepper variety "Kurtovska kapia" in the variant with a standard dose of mineral fertilizers was $41490 \mathrm{~kg} / \mathrm{Ha}$ and $37730 \mathrm{~kg} / \mathrm{Ha}$ on the reduced mineral background. Compared to the reduced mineral background, the increase in yield on a standard mineral background is 10 per cent. The processing of the pepper seeds with the humic acids "Nagro" and "Stimix", the treatment of the rhizosphere of the plant with the biological fertilizer "BioLife" and the soil introduction of the bioproduct "Trichodermine" before planting enhance the effect of application of the complex mineral fertilizers. In the variants with „Nagro" and „Stimex”, the increase in the yield is in the range of $19-24$ per cent depending on the amount of mineral fertilizers in the experiment.

On the reduced background of mineral fertilizers $\left(\mathrm{N}_{8} \mathrm{P}_{10} \mathrm{~K}_{11}\right)$, the effect of these preparations is higher than on the background created by the introduction of a full dose of mineral fertilizers $\left(\mathrm{N}_{16} \mathrm{P}_{20} \mathrm{~K}_{22}\right)$. The application of the bioproduct "Trichodermine" on a mineral background (NPK) increases the yield in the pepper field production by 27 per cent. A significant increase in yield of 29 per cent was observed with the introduction of "BioLife" on a mineral background $\left(\mathrm{N}_{16} \mathrm{P}_{20} \mathrm{~K}_{22}\right)$. This probably due to the fact, that BioLife helps the process of nitrifying and accelerating the absorption of the mineral nitrogen by bacteria.

An integrated system of organic and 
75 years of Agricultural University - Plovdiv JUBILEE SCIENTIFIC INTERNATIONAL CONFERENCE Plovdiv 26-28 November 2020
PERSPECTIVES ON AGRICULTURAL SCIENCE AND INNOVATIONS FOR SUSTAINABLE FOOD SYSTEMS mineral fertilizers improves the quality of the product. The percentage of standard fruits is the lowest in the reduced mineral variant $\left(\mathrm{N}_{8} \mathrm{P}_{10} \mathrm{~K}_{11}\right)-67$ per cent. In the variant using $\left(\mathrm{N}_{16} \mathrm{P}_{20} \mathrm{~K}_{22}\right)$, it is 88 per cent. For comparison,
89-98 per cent of standard production was obtained in variants using the organic products "Nagro", "Stimix", "Trichodermine" and "Biolife".

Table 1. The content of germs in soil samples during the years of the experiment.

\begin{tabular}{|c|c|c|c|c|c|c|c|c|c|c|}
\hline & \multirow{3}{*}{$\begin{array}{l}\text { Season/ } \\
\text { Variant }\end{array}$} & \multicolumn{9}{|c|}{ Number of microorganisms in $1 \mathrm{~g}$ of dry soil } \\
\hline & & \multicolumn{3}{|c|}{ Bacteria, $\mathrm{mn} / \mathrm{g}$} & \multicolumn{3}{|c|}{ Actinomycetes, $\mathrm{mn} / \mathrm{g}$} & \multicolumn{3}{|c|}{ Micromycetes, thsd/g } \\
\hline & & 1 & 2 & 3 & 1 & 2 & 3 & 1 & 2 & 3 \\
\hline \multicolumn{11}{|c|}{ Start of the Vegetation Period } \\
\hline & l sample & 1,17 & 1,11 & 1,14 & 0,09 & 0,14 & 0,12 & 31,65 & 45,00 & 38,33 \\
\hline \multicolumn{11}{|c|}{ The Middle of the Vegetation Period } \\
\hline 1 & $\left(\mathrm{~N}_{16} \mathrm{P}_{20} \mathrm{~K}_{22}\right)$ & 2,43 & 1,99 & 2,21 & 0,07 & 0,14 & 0,11 & 52,50 & 17,00 & 34,75 \\
\hline 2 & $\left(\mathrm{~N}_{8} \mathrm{P}_{10} \mathrm{~K}_{11}\right)$ & 0,87 & 1,87 & 1,34 & 0,23 & 0,18 & 0,21 & 26,50 & 27,00 & 26,75 \\
\hline 3 & $\begin{array}{l}\left(\mathrm{N}_{8} \mathrm{P}_{10} \mathrm{~K}_{11}\right)^{+}+ \\
\text {"Trihodermine" }\end{array}$ & 0,59 & 1,84 & 1,22 & 0,05 & 0,14 & 0,10 & 17,50 & 18,00 & 17,75 \\
\hline 4 & $\begin{array}{l}\left(\mathrm{N}_{8} \mathrm{P}_{10} \mathrm{~K}_{11}\right) \\
\text { "BioLife" }\end{array}$ & 1,44 & 2,34 & 1,89 & 0,07 & 0,27 & 0,17 & 20,00 & 28,00 & 24,00 \\
\hline 5 & $\begin{array}{l}\left(\mathrm{N}_{8} \mathrm{P}_{10} \mathrm{~K}_{11}\right)+ \\
\text { "Nagro" }\end{array}$ & 1,81 & 1,41 & 1,61 & 0,27 & 0,12 & 0,20 & 32,50 & 18,00 & 25,25 \\
\hline 6 & $\begin{array}{l}\left(\mathrm{N}_{8} \mathrm{P}_{10} \mathrm{~K}_{11}\right) \\
\text { "Stimix" }\end{array}$ & 0,66 & 2,10 & 1,38 & 0,33 & 0,17 & 0,25 & 25,00 & 16,00 & 15,50 \\
\hline \multicolumn{11}{|c|}{ The End of the Vegetation Period } \\
\hline 1 & $\left(\mathrm{~N}_{16} \mathrm{P}_{20} \mathrm{~K}_{22}\right)$ & 1,71 & 1,62 & 1,67 & 0,05 & 0,13 & 0,09 & 24,75 & 30,00 & 27,38 \\
\hline 2 & $\left(\mathrm{~N}_{8} \mathrm{P}_{10} \mathrm{~K}_{11}\right)$ & 0,63 & 1,20 & 0,92 & 0,04 & 0,20 & 0,12 & 11,75 & 36,00 & 23,88 \\
\hline 3 & $\begin{array}{lr}\left(\mathrm{N}_{8} \mathrm{P}_{10} \mathrm{~K}_{11}\right)^{+} \\
\text {"Trihodermine" }\end{array}$ & 0,52 & 0,51 & 0,52 & 0,18 & 0,10 & 0,14 & 20,00 & 27,00 & 23,50 \\
\hline 4 & $\begin{array}{l}\left(\mathrm{N}_{8} \mathrm{P}_{10} \mathrm{~K}_{11}\right) \\
\text { "BioLife" }\end{array}$ & 2,03 & 2,07 & 2,05 & 0,08 & 0,16 & 0,12 & 42,50 & 24,00 & 33,25 \\
\hline 5 & $\begin{array}{l}\left(\mathrm{N}_{8} \mathrm{P}_{10} \mathrm{~K}_{11}\right) \\
\text { Nagro }\end{array}$ & 0,64 & 1,50 & 1,07 & 0,18 & 0,13 & 0,47 & 13,00 & 12,00 & 12,50 \\
\hline 6 & $\begin{array}{l}\left(\mathrm{N}_{8} \mathrm{P}_{10} \mathrm{~K}_{11}\right)+ \\
\text { "Stimix" }\end{array}$ & 2,45 & 1,04 & 1,75 & 0,10 & 0,06 & 0,08 & 6,25 & 13,00 & 9,63 \\
\hline
\end{tabular}


75 years of Agricultural University - Plovdiv JUBILEE SCIENTIFIC INTERNATIONAL CONFERENCE Plovdiv 26-28 November 2020
PERSPECTIVES ON AGRICULTURAL SCIENCE AND INNOVATIONS FOR SUSTAINABLE FOOD SYSTEMS

Table 2. The structural composition of Micromycetes in soil samples.

\begin{tabular}{|c|c|c|c|c|c|c|c|c|c|}
\hline \multirow[b]{2}{*}{ № } & \multirow[b]{2}{*}{ Variant } & \multicolumn{8}{|c|}{ Fungi colonies in petri dishes, per $s p$.cent } \\
\hline & & 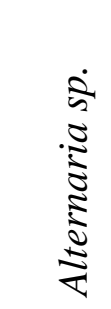 & 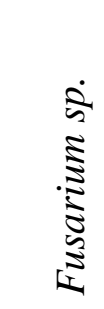 & 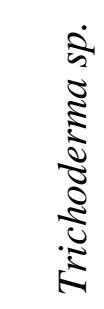 & 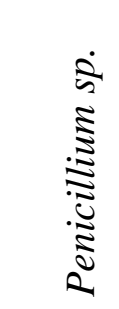 & 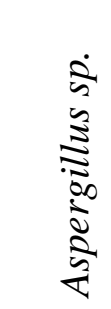 & 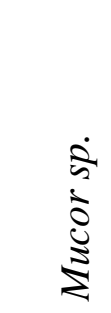 & 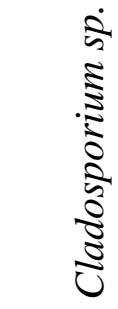 & 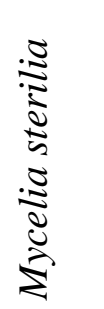 \\
\hline 1 & $\left(\mathrm{~N}_{16} \mathrm{P}_{20} \mathrm{~K}_{22}\right)$ & 17,65 & 5,89 & 0,00 & 5,89 & 17,65 & 43,00 & 5,89 & 10,00 \\
\hline 2 & $\left(\mathrm{~N}_{8} \mathrm{P}_{10} \mathrm{~K}_{11}\right)$ & 5,50 & 0,00 & 5,50 & 2,25 & 21,75 & 6,25 & 5,25 & 23,50 \\
\hline 3 & "Nagro" & 3,75 & 5,25 & 5,50 & 8,50 & 22,25 & 26,75 & 7,25 & 10,75 \\
\hline 4 & "Stimix" & 0,00 & 0,00 & 6,66 & 6,66 & 23,33 & 30,00 & 2,00 & 12,25 \\
\hline 5 & "Trichodermine" & 0,00 & 0,00 & 7,25 & 0,00 & 12,25 & 10,00 & 0,00 & 20,50 \\
\hline 6 & "BioLife" & 0,00 & 3,50 & 6,50 & 6,95 & 23,75 & 5,00 & 7,15 & 37,15 \\
\hline
\end{tabular}

Table 3. The influence of the organo-mineral system of fertilizers and bioproducts on the development of Alternaria black spots and the yield of sweet pepper.

\begin{tabular}{|l|c|c|c|c|c|}
\hline Variant & $\begin{array}{c}\text { Alternaria } \\
\text { black spots, } \\
\text { per cent }\end{array}$ & $\begin{array}{c}\text { Effect, } \\
\text { per cent }\end{array}$ & $\begin{array}{c}\text { Yield, } \\
\text { kg/Ha }\end{array}$ & $\begin{array}{c}\text { Effect, } \\
\text { per cent }\end{array}$ & $\begin{array}{c}\text { Standard } \\
\text { production, } \\
\text { per cent }\end{array}$ \\
\hline Control & 32,10 & - & 37730,01 & - & 66,76 \\
\hline$\left(\mathrm{N}_{16} \mathrm{P}_{20} \mathrm{~K}_{22}\right)$ & 29,55 & 7,94 & 41490,20 & 9,79 & 87,82 \\
\hline$\left(\mathrm{N}_{16} \mathrm{P}_{20} \mathrm{~K}_{22}\right)+$ Nagro & 14,5 & 54,82 & 46850,71 & 19,48 & 98,45 \\
\hline$\left(\mathrm{N}_{8} \mathrm{P}_{10} \mathrm{~K}_{11}\right)+$ Nagro & 17,55 & 45,33 & 50570,14 & 25,39 & 98,96 \\
\hline$\left(\mathrm{N}_{16} \mathrm{P}_{20} \mathrm{~K}_{22}\right)+$ Stimix & 20,55 & 35,98 & 48520,38 & 22,24 & 97,00 \\
\hline$\left(\mathrm{N}_{8} \mathrm{P}_{10} \mathrm{~K}_{11}\right)+$ Stimix & 17,05 & 46,88 & 49870,57 & 24,35 & 92,54 \\
\hline$\left(\mathrm{N}_{16} \mathrm{P}_{20} \mathrm{~K}_{22}\right)+$ Trichodermine & 14,05 & 56,23 & 49530,96 & 23,84 & 93,21 \\
\hline$\left(\mathrm{N}_{8} \mathrm{P}_{10} \mathrm{~K}_{11}\right)+$ Trichodermine & 13,97 & 56,48 & 52110,15 & 27,60 & 97,72 \\
\hline$\left(\mathrm{N}_{16} \mathrm{P}_{20} \mathrm{~K}_{22}\right)+$ BioLife & 28,65 & 10,75 & 53580,73 & 29,59 & 89,21 \\
\hline$\left(\mathrm{N}_{8} \mathrm{P}_{10} \mathrm{~K}_{11}\right)+$ BioLife & 23,25 & 27,57 & 43880,89 & 14,033 & 94,81 \\
\hline
\end{tabular}


75 years of Agricultural University - Plovdiv

JUBILEE SCIENTIFIC INTERNATIONAL

CONFERENCE Plovdiv 26-28 November 2020
PERSPECTIVES ON AGRICULTURAL SCIENCE AND INNOVATIONS FOR SUSTAINABLE FOOD SYSTEMS

\section{CONCLUSIONS}

The quantity of imported mineral fertilizers affects the biological activity of the soil. The introduction of the standard dose of mineral fertilizers $\left(\mathrm{N}_{16} \mathrm{P}_{20} \mathrm{~K}_{22}\right)$ strengthens the process of biological activity.

The use of the bioproducts „Trihodermine”, „Stimix” and „BioLife” optimizes soil health at the expense of the less fungal colonies in variants with bio-products.

The effect of bioproducts is better expressed on the reduced mineral background.

The introduction of bioproducts on the reduced mineral background creates favourable conditions for the development of the microorganisms of all major groups. This ensures the stability of the functional links between the major ecological trophic groups of microorganisms.

The efficacy of „Trihodermine” against Alternaria black spots in the pepper crop is 56 per cent. In variants with the use of "Nagro" for seed treatment, the disease reduction is 45 per cent on background $\mathrm{N}_{8} \mathrm{P}_{10} \mathrm{~K}_{11}$ and 55 per cent on background $\mathrm{N}_{16} \mathrm{P}_{20} \mathrm{~K}_{22}$.

The application of the integration system for fertilization (organic, mineral fertilizes and the bio-product ,Trihodermine” increases the yield and the percentage of the standard pepper production in field conditions. The increase of the yield is $19-24$ per cent with the application of "Nagro" and „Stimix” bio-fertilizes, 23 per cent - „Trichodermine” and 29 per cent - „BioLife”.

\section{ACKNOWLEDGMENT}

This work was supported by the Bulgarian Ministry of Education and Science under the National Research Programme "Healthy Foods for a Strong Bio-Economy and Quality of Life" approved by DCM \# 577 / 17.08.2018".

\section{REFERENCES}

Apone, F. 2010. A mixture of peptides and sugars derived from plant cell walls increases plant defense responses to stress and attenuates ageing-associated molecular changes in cultured skin cells. Journal of Biotechnology, v. 145 (4): 367-376.

Bakker, M., D. Schlatter, L. Otto-Hanson, L. Kinkel. 2014. Diffuse symbioses: roles of plant-plant, plant-microbe and microbe-microbe interactions in structuring the soil microbiome. Mol. Ecol. 23: 1571-1583.

Belakbir, A., J. Ruiz, L. Romero. 1998. Yield and fruit quality of pepper (Capsicum annuum L.) in response to bioregulators. HortScience, 33: 85-87.

Bhattacharyya, P., D. Jha. 2012. Plant growth promoting rhizobacteria (PGPR): emergence in agriculture. World $\mathrm{J}$. Microbiol. Biotechnol. 28: 1327-1350.

Brown, P., S. Saa. 2015. Biostimulants in agriculture. Front Plant Sci. 6: 671.

Chulkina, V. 1995. Management of agroecosystems in the protection of plants Novosibirsk: In: REVIK. 202 p.

Craigie, J.S. 2011. Seaweed Extract Stimuli in Plant Science and Agriculture. Journal of Applied Phycology, 23: 371-393.

Colla, G., Y. Rouphael, E. Di Mattia, C. ElNakhel, M. Cardarelli. 2015. Coinoculation of Glomus intraradices and Trichoderma atroviride acts as a biostimulant to promote growth, yield and nutrient uptake of vegetable crops. J. Sci. Food Agric. 95: 1706-1715.

Di Marco, S., F. Osti. 2009. Effect of biostimulant sprays on Phaeomoniella chlamydospora and esca proper infected vines under greenhouse and field conditions. Phytopathol. Mediterr. 48: 47-58.

Dixon, G., U. Walsh. 2004. Suppressing 
75 years of Agricultural University - Plovdiv JUBILEE SCIENTIFIC INTERNATIONAL CONFERENCE Plovdiv 26-28 November 2020
PERSPECTIVES ON AGRICULTURAL SCIENCE AND INNOVATIONS FOR SUSTAINABLE FOOD SYSTEMS
Pythium ultimum induced damping-off in cabbage seedlings by biostimulation with proprietary liquid seaweed extracts managing soil-borne pathogens: a sound rhizosphere to improve productivity in intensive horticultural systems, in Proceedings of the XXVI Inter. Horticultural Congress (Toronto).

Du Jardin. P. 2015. Plant biostimulants: Definition, concept, main categories and regulation. Scientia Horticulturae, v. 196 (30): 3-14.

Fuentes-Ramirez, L., E. Caballero-Mellado J. 2006. Bacterial biofertilizers, in PGPR: Biocontrol and Biofertilization. (Dordrecht: Springer), pp.143-172.

Gannibal, Ph.. 2011. Monitoring of alternarioses of crops and identification of fungi of the genus Alternaria. A manual. Ed. M. Levitin. VIZR, St. Petersburg. $70 \mathrm{p}$.

Georgieva, O. 2013. The effect of organic fertilizers and biological plant protection products on the development of diseases in field tomatoes. The scientific and practical Journal "Gavrish", Moscow. 6: 40-42.

Hernandez, O., A. Calderín, R. Huelva, D. Martínez-Balmori, F. Guridi, $N$. Aguiar. 2015. Humic substances from vermicompost enhance urban lettuce production. Agron. Sustain. Dev. 35: 225-232.

Hernandez-Herrera, $\quad$ R., $\quad F . \quad$ SantacruzRuvalcaba, M. Ruiz-Lopez, J. Norrie, G. Hernandez-Carmona. 2014. Effect of liquid seaweed extracts on growth of tomato seedlings (Solanum lycopersicum L.). J. Appl. Phycol. 26: 619-628.

Ikrina, M., A. Kolbin. 2004. Regulators of Plant Growth and Development, Vol. 1: Stimulants. Moscow, "Chemistry".

Linser A., L. Cazzara, G. Barbieri. 2006. Plant growth promoting rhizobacteria: a new opportunity for a sustainable agriculture. Fertilitas Agrorum. 1: 6575.

Mora, V., E. Bacaicoa., A.-M Zamarreño., E. Aguirre, M. Garnica, M. Fuentes. 2010. Action of humic acid on promotion of cucumber shoot growth involves nitrate-related changes associated with the root-to-shoot distribution of cytokinins, polyamines and mineral nutrients. J. Plant Physiol. 167, 633642.

Yegoshin, A.Ya. 2008. Ecological system of plant protection and productivity of arable land. In: Protection and quarantine of plants. 3: 25-26.

Rudakov, V. 2006. Biological method in the system of plant protection. Journal of Greenhouse Technologies: 3 (8): 1-5.

Yakovlev, I. 2006. Influence of a seminal infection on defeat of spring wheat by root rot. In: Protection and quarantine of plants. 2:57-59.

Yakhin, O., A., Lubyanov, I., Yakhin, P. Brown. 2017. Biostimulants in Plant Science: A Global Perspective. Front. Plant Sci., v. 7: 1-32.

Zvyagintsev, D. 1991. Methods of Soil Microbiology and Biochemistry. Moscow: MSU Publishing House. 304 p. 